\title{
Newcastle dy University
}

\section{Newcastle University ePrints}

\author{
Gibbon J, Haynes K. Building Excellence as an Internationally Recognised \\ Business School. In: Murray, A., Baden, D., Cashian, P., Wersun, A. and \\ Haynes, $\mathrm{K}$, ed. Inspirational Guide for the Implementation of PRME: UK and \\ Ireland Edition. Sheffield, UK: Greenleaf, 2014, pp.29-36.
}

\section{Copyright:}

C2014 Greenleaf Publishing

The definitive version of this book chapter, published by Greenleaf Publishing, 2014, is available through:

http://www.greenleaf-publishing.com/productdetail.kmod?productid=3987

Always use the definitive version when citing.

Further information on publisher website: http://www.greenleaf-publishing.com

Date deposited: $14-10-2014$

Version of file: Accepted Author Manuscript

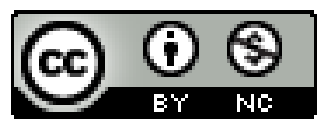

This work is licensed under a Creative Commons Attribution-NonCommercial 3.0 Unported License ePrints - Newcastle University ePrints http://eprint.ncl.ac.uk 


\section{Building Excellence as an Internationally Recognised Business School \\ Jane Gibbon and Kathryn Haynes}

Newcastle University Business School

\section{Introduction/background}

Newcastle University Business School (NUBS) first signed a commitment to the Principles for Responsible Management Education (PRME) in December 2009 and has consolidated and affirmed its responsibility within two Sharing Information on Progress (SIP) reports.

In today's global business environment, a good management education can provide a crucial foundation upon which to build a better world. NUBS continues to develop its provision to support new generations of leaders who will address the increasingly complex challenges that are faced by society. NUBS is committed to providing management education that responds to these ever increasing demands. The Banking Crisis of 2007-08 and recent corporate governance scandals provide examples of how conventional approaches to business education can no longer meet the needs of the marketplace.

The School has recently revised its vision, mission and values, strengthening its commitment to responsible management education. The vision and mission incorporate the need to be innovative and are reinforced through four values that characterize all NUBS' activities. These four values are: conscientiousness and integrity; curiosity and openness; critical relevance; and creativity in all areas.

The particular achievements that demonstrate a commitment to PRME during the last two years are: the continued development of engagement with all stakeholders; the School's contribution to the University's societal themes of Sustainability and Social Renewal; activities within academic subject groups; developments within the teaching provision; and current research and publications from research groups.

NUBS has developed a strong vision that embraces the core of PRME through the aspiration to be an internationally recognized Business School. Its aim is to have a world-leading research reputation across a range of disciplines, including: critical accounting; economics; human resources management; innovation systems; services marketing; and strategy, organisations and society. The School will further develop its distinctive pedagogy based on the 'Theory of Application' approach, incorporating a more blended learning style and a commitment to Lifelong Learning, producing a student experience that is highly rewarding and challenging. It continues to work with partners and external organisations, from international corporates to local voluntary organisations, to both develop and strengthen the commitment to PRME. 


\section{Challenge}

Newcastle University prides itself as being a world-class civic university, by which we mean responding to the needs and demands of civil society and serving as a public good. As a civic university with a global reputation for academic excellence, Newcastle University is committed to solving, rather than describing, the great challenges of our age, and thus helping frame a more optimistic global debate.

Newcastle University's motto is "Excellence with a purpose". The commitment of Newcastle University Business School in being a signatory to the Principles of Responsible Management Education (PRME) demonstrates this purpose. Newcastle University is a civic university with a role to play in society by bringing both research and teaching to bear on issues faced by local, national or international communities.

In response to the great challenges of our age Newcastle University has three Societal Challenge Themes and is committed to ensuring the outcomes of research help to address some of the key global issues by focusing on these themes as part of our overall focus on excellence with impact. The research, teaching and engagement activities of Newcastle University Business School are closely linked to the three Societal Challenge Themes of Ageing, Social Renewal, and Sustainability. These three themes address the demand side of research by responding to some of the most pressing needs within society.

\section{What we did}

Newcastle University Business School has taken the role of the civic university as a key focus by incorporating the values of global social responsibility, as portrayed in international initiatives such as the United Nations Global Compact, into academic activities and curricula. One development within the School was to revise the vision, mission and values of the School in order to reflect and underpin the School's commitment to being a signatory of PRME. The process of consultation resulted in the following vision, mission and values for the School:

\section{Vision}

To be an internationally recognised business school by being regionally rooted, nationally influential and globally respected.

\section{Mission}

We add value to all stakeholders through building excellence in teaching, research and engagement activity and provide new, global perspectives and the inspiration to contribute to the responsible and ethical shaping of society. 


\section{Values:}

\section{Conscientiousness and integrity}

In everything we do, we strive to change the world for the better, through socially and ethically responsible practice and respect for fellow human beings. We are aware of the impact our work has on the world around us and are deliberate in the relationships we forge and sustain on behalf of our staff, students, and stakeholders.

\section{Curiosity and openness}

We encourage open minds and a fascination around the edges, as well as the traditional core, of business education. In an ever-changing world, our students and staff must be ready to embrace innovation, take action, and work across disciplines to see beyond the accepted norms.

\section{Critical relevance}

Through our research, teaching and engagement, we reflect upon those critical perspectives that influence global policy and practice. We demonstrate relevance and value in an external context by thinking critically and engaging with new ideas.

\section{Creativity in all areas}

We value creative, collaborative approaches to work inside and outside the traditional university environments. Taking inspiration from the worlds of practice, especially the technological and design-led arenas, we will seek innovative ways of teaching, learning, and applying our theory into practice.

\section{What happened}

The challenge was how to incorporate the vision, mission and values across a large and diverse School so that it is embedded in our learning, teaching and student experience; research; and partnerships.

\section{Learning, Teaching and Student experience}

Newcastle University Business School is organised around four subject areas: Accounting and Finance; Economics; Leadership, Work and Organisation; and Marketing, Operations and Systems. Through the subject areas, NUBS provides a diverse and complex provision of programmes that provide strong links to the issues and demands of managing organisations and the social and environmental impacts of all business enterprises. An example of added value and good practice in relation to student experience is the Global Experience Opportunities offered to NUBS' students, enabling them to take part in unique opportunities to ensure they have a broader globally responsible perspective in an ever changing world. The opportunities support them in achieving their career aspirations and internationalise their student experience. The Global Experience Opportunity is an easily accessible offering to all students across the School and introduces them to the international business community whilst developing practical skills needed to succeed in global markets. Other 
opportunities open to students are Summer internships, Summer School Programmes, 12 month placements, Global Competitions and Global study opportunities.

Research

NUBS is part of a research-intensive University and there is a thriving research community with links extending across the world. Research is of key importance to all activities within the School where:

- it is a vital part of the contribution made by members of the School to develop better understanding of the issues facing managers, professionals and policy-makers

- it is central to how the School can engage directly with organisations and policy-makers at regional, national and international levels

- it provides the foundation for teaching at all levels, ensuring that students are exposed to knowledge and approaches that reflect the latest thinking and are grounded in practice

Since the Business School was formed, the focus has been on conducting and disseminating research of the highest international standard, which contributes to and influences policy and practice.

The School's research activity is conducted through Research Groups with the work that supports PRME primarily conducted within the following research groups:

- $\quad$ Centre for Knowledge, Innovation, Technology and Enterprise (KITE)

- Accounting, Governance and Accountability (AGA)

- Economics

- Gender, Professions and Society

- Human Resource Management, Work and Employment (HRMWE)

- Services Marketing

- Strategy, Organizations and Society (SOS)

\section{Partnerships}

Partners are another key element of the School's work; the International Advisory Board (IAB) has supported Newcastle over a number of years. Its role is to help bring the School's vision to life, provide strategic guidance and, importantly, independent advice and sound judgment. Members of the IAB represent strands of the renewed vision, and are all highly accomplished and experienced people in their own fields. The rich mixture of diverse talent is of tremendous value to the School as their knowledge and skills, grounded in the realities of business management, academic and public life, provide a great sounding board for the Business School. Members' networks further enhance the excellent links, active dialogue and engagement the School already has with the business community.

NUBS is also sponsoring the North East Institute of Business Ethics (NIBE), which was created in 2013, linking NUBS' Ethics Forum with a widely-representative group of regional business people. 
This partnership supports NIBE as an independent regional resource overseen by an influential crosssector steering group with an aspiration to become a focal point for good business behaviour.

The David Goldman Visiting Professorship in Innovation and Enterprise is another key partnership for the School. The position is awarded each year to a leading entrepreneur or business leader from within the region who provides inspiration and motivation to budding entrepreneurs and business leaders. The role involves working with the School to provide leadership and mentoring to students and faculty, and also delivering the David Goldman Annual Business School Lecture.

\section{What next}

NUBS plans to continue and extend the commitment to PRME by further embedding the work already being conducted across research, teaching and learning, and engagement activities. These activities are closely linked to all the work involved with the accreditation bodies:

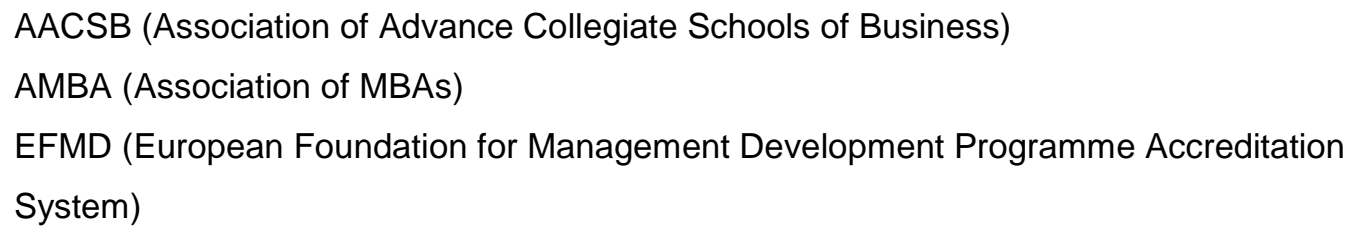

As a signatory to the UK and Ireland Chapter of PRME, NUBS supports the development of PRME within UK Business Schools. The support is expected to be through attendance at Chapter meetings, hosting seminars, workshops and invited speaker events, as well as continually working on embedding the PRME principles into all activities.

The Global Experience Initiative will provide a key contribution in extending the programme of internationalization for teaching and learning. The plan is to further enhance and extend these initiatives in the future.

NUBS will continue to bring together business leaders, students and academics through initiatives to develop further links for dialogue, research and engagement. NUBS is committed to educating responsible business leaders and global citizens who are equipped to manage in future business environments that are global, complex, and sustainable. The School is committed to developing the potential of its students by providing them with a sound theoretical and practical training that focuses on innovative thinking, entrepreneurship, accountability, governance, ethics and social responsibility. The School believes that this can be achieved through teaching, research and engagement within a Business School that strives to implement sustainable and ethical practices.

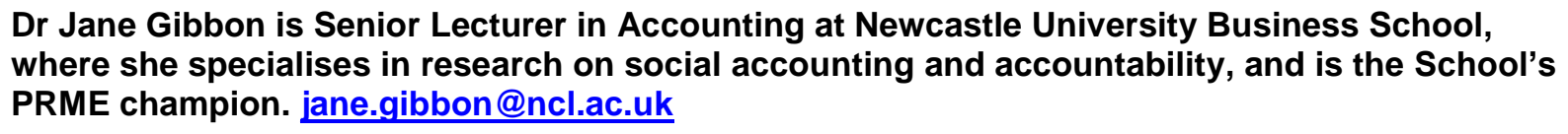
where she specialises in research on social accounting and accountability, and is the School's PRME champion. iane.gibbon@ncl.ac.uk 
Professor Kathryn Haynes holds the Northern Society Chair in Accounting \& Finance at Newcastle University Business School where she is Deputy Director of the School, and Head of the Gender, Professions and Society Research Group. She is a Co-facilitator of the PRME Gender Equality Working group. kathryn.haynes@ncl.ac.uk 